\title{
Analysis of a chicken wing cut sector using the OWAS method
}

\author{
Ana Sophia Rosado ${ }^{1}$, Carolina Garreto², J. Duarte ${ }^{3}$ \\ ${ }^{1}$ Faculty of Engineering, University of Porto, PT (anasgmr@yahoo.com.br) ORCID: 0000-0002-4935-4171, ${ }^{2}$ Faculty of Engineering, University \\ of Porto, PT (carolgarreto@gmail.com) ORCID 0000-0001-7138-7714, ${ }^{3}$ Associated Laboratory for Energy, Transports, and Aeronautics \\ (PROA/LAETA), Faculty of Engineering, University of Porto, PT (jasduarte@fe.up.pt) ORCID 0000-0002-5856-5317 \\ https://doi.org/10.24840/978-972-752-260-6_0005-0009
}

\begin{abstract}
Introduction: The Industrial Revolution has encouraged consumption and, consequently, the competitiveness of the market. Historically, it can be perceived as the evolution of the industrial process. However, despite the implementation of automation, many industrial activities continue to be repetitive and monotonous, such as the first industries in which maximum production was required at the lowest cost. The still persistent production model can cause physical stress by the uninterrupted repetition of movements and force requirement, and psychological stress due to monotony and overloads. Despite the improvements in working conditions and awareness about the importance of occupational health and safety, there is too much charge about the goal, productivity and product quality, factors that cause stress physical and psychological to the worker. The physical stress tends to favor the development of musculoskeletal injuries that, when occurring in the workplace, are called occupational diseases. The objective of this research was to observe the work position especially the posture adopted by the workers in a chicken wing cut sector. Methodology: The observation allowed the ergonomic analysis with the use of the Ovako Working Posture Analyzing System (OWAS) method and subsequent comparison of the results obtained to the reality experienced by the workers, namely, the index of musculoskeletal injuries in the sector. For the research, the observation in situ of the activities was performed and the ergonomic risk was evaluated by the OWAS method to assess the ergonomic risks of the postures based on the position of the back, arms, and legs in an industrial sector which activity is exclusively the cut of the chicken wing. Results and discussion: The analysis of the times and methods, as well as the medical records of all the workers of the sector, were registered and assessed. For statistical analysis, workers were divided into a) uptime, b) workers who had already exercised demanding work activity of physical exertion and/or repetition of movements and the form of removal (with medical low or without medical low) and, c) by gender. It was observed the ergonomic risk of activity by the OWAS method and the percentage of injured workers, which was possible by analyzing the medical records. There was disagreement between the result of the ergonomic method and the number of injured workers. It is believed that this happened since the method does not consider the repetition of movements that is exhaustive in the activity. Conclusions: It was also found that the same activity performed in identical conditions tends to be more harmful to females. Since the ergonomic analysis is performed using several tools, it is believed that the result is reliable, given the dissonances that may exist between methods and means of analysis.
\end{abstract}

Keywords. Occupational disease, Work-related musculoskeletal disorders, Posture.

\section{INTRODUCTION}

Most of the work-related musculoskeletal disorders (WMSD) develop over time. Usually, there is no single cause for these injuries (EU-OSHA, 2019). The WMSD are associated with certain types of activity, Santos (2015) suggests that the main occupational risk factors originating in the work activity are posture, repeatability, strength, and exposure to vibrations. MWSD are lesions that have different factors in their origin and their symptomatology is a direct or indirect consequence of morphological and functional alterations that are induced in the motor, sensory and neurovegetative system (Ranney, 2000). Succinctly, it can be said that WMSD are lesions that result from the action of professional risk factors such as repeatability, overload and/or posture adopted during work (Uva, Carnide, Serranheira, Miranda, \& Lopes, 2008). WMSD are considered occupational diseases as it falls within the definition: "Illness contracted by the worker following exposure to one or more risk factors present in the professional activity, working conditions and/or techniques used during the work" (Direção-Geral da Saúde, 2014). WMSD is usually due to muscular fatigue, which is the effect of continuous work, which causes a reversible reduction of the organism's capacity, being caused by a set of factors (lida, 2005). In order to elide or minimize the incidence of WMSD, there are in-depth studies on ergonomics, which is the science that studies "the adaptation of work to man" (Crespaumer, Brito, Melo, \& Correa, 2015). The ergonomic analysis of jobs is a method for defining and evaluating working conditions. A general assessment may lead to deeper analysis or correction of unsatisfactory 
working conditions (Costa, 2004). Ergonomics is seen as the application of the biological sciences in conjunction with the engineering sciences to achieve the optimum adjustment of the human being to their work and to ensure, simultaneously, efficiency and well-being (Superior, Empresariais, Guterres, \& Sobral, 2014). Abranches (2005) adds that ergonomics has an interdisciplinary character that deals with the optimization of working conditions aiming at an integrated approach of the safety, health, and comfort of the worker and the efficiency of the quality and quantity of production. The ergonomic analysis aims to verify and, if possible, to rebut or minimize adverse situations to the musculoskeletal structure of the worker because they can result in decreased productivity, which is essential in the current market conjuncture increasingly competitiveness (Cohn, Hirano, Karsch, \& Sato, 2015). The objective of the study is to evaluate the postures adopted by the workers in order to verify the risks of developing musculoskeletal injuries and to compare the result to the reality experienced through the analysis of medical records.

\section{METHODOLOGY}

The study analyzed the chicken wing cutting sector, in a slaughterhouse located in southern Brazil. The company has a population of 1300 employees, 40 of them working in the wing cutting sector (20 workers per shift). It is important to emphasize that the population analyzed consists of $66.7 \%$ of female and $33.3 \%$ of male, with a mean age of 36 and 40 years old respectively. All workers had their medical records evaluated. However, the postural observation was performed to, approximately, one-third of them, emphasizing that all the workers perform the function exactly the same way. The company has two production shifts, including three pauses of 20 minutes and 1 hour for lunch break, as observable in Table 1.

Table 1. Shifts and pauses

\begin{tabular}{|c|c|c|c|c|c|}
\hline $\begin{array}{l}\text { Work shift } \\
\text { start }\end{array}$ & $1^{\text {st }}$ break & $2^{\text {nd }}$ break & Lunch break & $3^{\text {rd }}$ break & $\begin{array}{l}\text { Work shift } \\
\text { end }\end{array}$ \\
\hline 4:00 a.m. & $\begin{array}{l}\text { 5:40 a.m. to } \\
\text { 06:00 a.m. }\end{array}$ & $\begin{array}{l}\text { 07:40 a.m. to } \\
08: 00 \text { a.m. }\end{array}$ & $\begin{array}{l}\text { 09:40 a.m. to } \\
\text { 10:40 p.m. }\end{array}$ & $12: 00$ to $12: 20$ & 1:29 p.m. \\
\hline 2:00 p.m. & $\begin{array}{l}\text { 3:40 p.m. to } \\
\text { 4:00 p.m. }\end{array}$ & $\begin{array}{l}\text { 5:40 p.m. to } 6: 00 \\
\text { p.m. }\end{array}$ & $\begin{array}{l}\text { 7:40 p.m. to } 8: 40 \\
\text { p.m. }\end{array}$ & $\begin{array}{l}\text { 10:00 p.m. to } \\
\text { 10:20 p.m. }\end{array}$ & 11:30 p.m. \\
\hline
\end{tabular}

The analysis was developed in January 2017 through sector observation in situ, and photographic record. The chosen instrument to do so was the Ovako Working Posture Analyzing System (OWAS) method which aims to generate information to improve working methods by identifying harmful body postures during the performance of activities (Másculo \& Vidal, 2011). The OWAS Tool offers a simple method for analyzing work postures. The results generated are based on the positioning of the spine, arms, and legs, as well as considering the loads and forces used. The method was used in its original form, including the spine, arms, and legs, as well as the carry of loads or use of force, after the observations of the postures of approximately 14 workers (one-third of all employees in the sector) in a slaughterhouse, crowded in the wing cutting sector. The score attributed to the evaluated posture indicates the urgency in taking corrective measures to reduce the exposure of workers to risks (Masculo \& Vidal, 2013). The method scores in ascending order of severity according to the value assigned to the back and arms from 1 to 3 , and the legs score from 1 to 7 . The force performed by the worker (the knife weight used do cut the wing) was also analyzed. Therefore, to each posture assumed by a 
worker, it was attributed a 4-digit code that depended on the classification within the previous postures for each part of the body, and the respective load (Gómez-Galán, Pérez-Alonso, Callejón-Ferre, \& López-Martínez, 2017). After analyzing the body and the force, the general table of scores is used. The intersection of the results obtained will generate a final numerical risk result from 1 to 4 , being 1 considered a normal posture and 4 a posture that requires immediate attention. The medical records of the workers of the chosen industrial sector responsible for the cutting of chicken wings were also analyzed, with the objective of verifying the incidence of musculoskeletal injuries and highlighting the more evident results. The most relevant data analyzed were sex, age, admission (uptime), medical leave, days, ICD (International Code of Diseases), social security benefits, previous function, period worked. The data obtained allowed a statistical perception of the population most affected by musculoskeletal disorders.

\section{RESULTS AND DISCUSSION}

In the company under analysis, an average slaughter of 50,000 chicken per shift is made. The work pace is 7,500 products per hour, which equals 125 products per minute. Considering that each product has 2 wings it equals 250 products per minute. There are 20 employees in the sector per shift (in the wing cutting machine), so the pace of work per employee is 12.5 products every minute; each product has 2 wings, which means 25 cuts per minute, per employee. The weight and dimensions of the knife used are negligible for the analysis. The force exerted by the workers in the execution of the wing cut was not measured. However, by the simple analysis, it was realized that it is enough to lean the knife in the skin of the animal so that the cut occurs. The collaborators position themselves standing in front of the products, with no back rotation. As for the position of the upper limbs, the arms move up and down continuously. The scores obtained with the application of the OWAS method are presented in Table 2.

Table 2. OWAS method results

\begin{tabular}{llc}
\hline Task: WING CUTTING & & \\
\hline Body part & Position & Pontuation \\
\hline Back posture & Upright & 1 \\
\hline Forearms & One above elbow joint & 2 \\
\hline Legs & Standing with one leg upright & 2 \\
\hline ANALYSIS RESULT & & 1 \\
\hline
\end{tabular}

Regarding the statistics of the occupational diseases, the medical records were used, having been considered: employees with less than two years in the company, two to five years and more than five years. Moreover, other situations such as workers with a medical certificate without social security clearance (period less than 15 days), with a social security clearance (period exceeding 15 days) and workers with previous demanding functions of the upper limbs were verified. Figure 1 shows the incidence of musculoskeletal injuries in women and Figure 2 depicts the incidence in men. By the statistical analysis made with the data from medical records, it was found that $25 \%$ of the women hired by the company between 2 and 5 years had clearance with medical certificate due to musculoskeletal injuries of the upper limbs, a very harmful impact on productivity. Considering the same period -2 to 5 years - in the male 
population, there were $8 \%$ of injured patients with medical leave. Although the withdrawal period was longer than in the female population, the index of injured men is significantly lower.

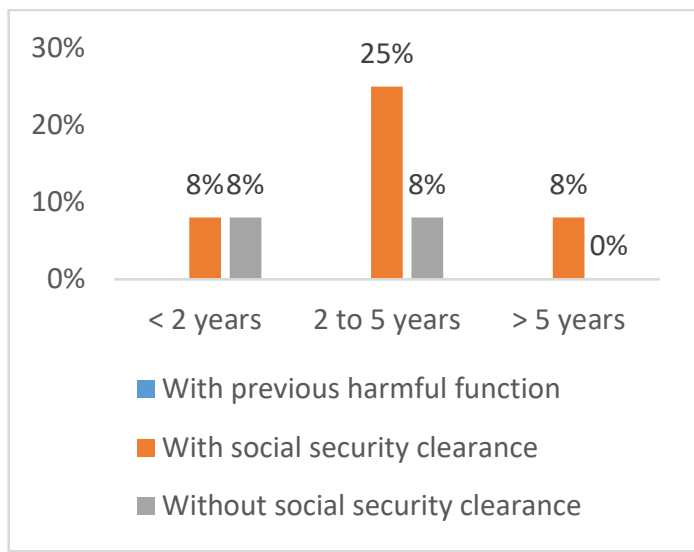

Figure 1. Injured women

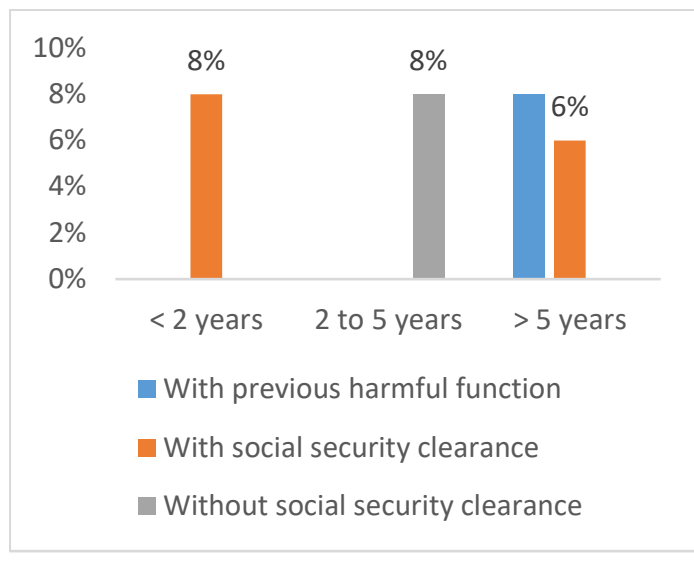

Figure 2. Injured men

Although the result of the analysis by the OWAS method was at risk level 1 (normal posture), there is activity movements repetition of the upper limbs throughout the working day. The repetition of movements is not considered in OWAS analysis. In this sense, Pedro \& Martins (2009) describe it as an observational method to evaluate spine posture, upper and lower limbs and muscular strength involved. There is no information about the cadence of the cycle and repetition of movements. Regarding musculoskeletal injuries, studies have shown that the incidence is higher among young workers, with women being the most affected, with a prevalence of between 20 and 39 years (Walsh et al., 2004). Another study in a slaughterhouse about the risks of musculoskeletal injury concluded that most of the collaborators presented some type of pain, most of them in the upper limbs (Pereira, Fernandes, Ramos, \& Taque, 2016). The present study showed that women with mean age 36 are the most affected and also that many workers felt some pain throughout the contractual.

\section{CONCLUSIONS}

The ergonomic analysis by the OWAS method considered that the adopted posture is ergonomically normal. However, the analysis of medical records showed that in the sector there is an incidence of musculoskeletal injuries, especially in the female population. The analysis by the used ergonomic method provides data of interest, but it is not enough. Knowing that the human body is not an exact machine, it is important that the analysis is accompanied by other complementary methods. It is believed that the lesions occurred by the exhaustive repetition of movements of the upper limbs since the repetition of movements is not considered in the analysis of the OWAS method. By the analysis of medical records, it can be said that the female population tends to be injured more frequently. There are studies that emphasize the fragility of female physical complexion as compared to men, which would bring damage to the musculoskeletal structure when subjected to the same activity, effort, and conditions. The results obtained by the OWAS analysis and by the medical records were divergent since both have a different focus of analysis. This indicates that the analyses should use more than one method so the result can be reliable and conducted more accurately. It was concluded that it is 
necessary to communicate with the workers and to raise awareness about occupational diseases (Pereira et al., 2016).

\section{References}

Abranches, S. S. (2005). A situação ergonômica do trabalho de enfermagem em unidade básica de saúde. Ergonomia. UNIVERSIDADE DE SÃO PAULO ESCOLA. https://doi.org/10.11606/T.22.2005.tde-07122005-104056

Cohn, A., Hirano, S., Karsch, S. U., \& Sato, A. (2015). DA REVOLUÇÃO INDUSTRIAL AO MOVIMENTO OPERÁRIO: As origens do mundo contemporâneo.

Costa, L. G. (2004). Guia do Finish Institut of Occupational Health para Análise Ergonómica de Postos de Trabalho. Retrieved from http://www.crpg.pt/empresas/recursos/kitergonomia/Documents/EWA_Português_2004.pdf

Crespaumer, V., Brito, F., Melo, C., \& Correa, A. (2015). Aplicação Do Método Owas E Análise Ergonômica Do Trabalho Em Um Segmento De Uma Empresa De Grande Porte Situada No Mucinípio De Campos Dos Goytacazes. XXXV Encontro Nacional de Engenharia de Produção.

Direção-Geral da Saúde. (2014). Programa Nacional de Saúde Ocupacional. Retrieved March 11, 2019, from https://www.dgs.pt/saude-ocupacional/doencas-profissionais-e-acidentes-de-trabalho/doencas-profissionais.aspx

EU-OSHA. (2019). Lesões musculosqueléticas. Retrieved March 14, 2019, from https://osha.europa.eu/pt/themes/musculoskeletal-disorders

Gómez-Galán, M., Pérez-Alonso, J., Callejón-Ferre, Á.-J., \& López-Martínez, J. (2017). Musculoskeletal disorders: OWAS review. Industrial Health. https://doi.org/10.2486/indhealth.2016-0191

lida, I. (2005). Ergonomia: projeto e produção. São Paulo: Editora Edgard Blucher.

Masculo, F. S., \& Vidal, M. C. (2013). Ergonomia: trabalho adequado e eficiente. Elsevier Brasil.

Másculo, F. S., \& Vidal, M. C. (2011). Ergonomia - Trabalho Adequado e Eficiente - Francisco Soares Másculo;Mario Cesar Vidal. Elsevier Brasil.

Pereira, J. A. da S., Fernandes, T., Ramos, M. T. S., \& Taque, C. M. W. (2016). OS RISCOS DE LER / DORT NA DESOSSA DE UM ABATEDOURO BOVINO, 100-110.

Ranney, D. (2000). Distúrbios osteomusculares crônicos relacionados ao trabalho. São Paulo: Roca. São Paulo.

Santos, A. R. V. (2015). Lesões musculoesqueléticas relacionadas com o trabalho nos enfermeiros em contexto hospitalar. Escola Superior de Enfermagem de Coimbra.

Superior, E., Empresariais, C., Guterres, M. J., \& Sobral, C. (2014). Instituto Politécnico de Setúbal Análise e Intervenção Ergonómica em Postos de Trabalho com Computadores: A Perceção dos Trabalhadores. Instituto Politécnico de Setúbal. Retrieved from https://comum.rcaap.pt/bitstream/10400.26/6657/1/Dissertação SHT_MariaJoaoSobral_FINAL.pdf

Uva, A., Carnide, F., Serranheira, F., Miranda, L., \& Lopes, M. F. (2008). Lesões Musculoesqueléticas Relacionadas com o Trabalho: Guia de Orientação para a Prevenção. Programa Nacional Contra as Doenças Reumáticas, 28. https://doi.org/274779/08

Walsh, I. A. P., Corral, S., Franco, R. N., Canetti, E. E. F., Alem, M. E. R., \& Coury, H. J. C. G. (2004). Capacidade para o trabalho em indivíduos com lesões músculo-esqueléticas crônicas. Revista de Saude Publica, 38(2), 149-156. 